This is an author-produced postprint of an article published in the Journal of Peacebuilding and Development (published online 31 August 2020; print publication in 2021as part of the Special Edition on Varieties of Peace). Please cite as

Howell, G. (2020) Harmonious relations: A framework for studying varieties of peace in music-based peacebuilding. Journal of Peacebuilding and Development [Online First].

\title{
Harmonious relations: A framework for studying varieties of peace in music-based peacebuilding
}

\author{
Gillian Howell, Faculty of Fine Arts and Music, The University of Melbourne \\ Queensland Conservatorium Research Centre, Griffith University (adjunct)
}

\begin{abstract}
:
This article presents an analytical framework for systematically studying the relationships portrayed within music-based peacebuilding and their respective representations of peace. Music activities with peacebuilding objectives work predominantly within a relational concept of peace, bringing into existence relationships between sounds, people and spaces through which behaviours such as non-dominance and cooperation can be enacted. However, each of these relationships can communicate different ideas about peace and its manifestation, communications that may be inconsistent with each other and with the activity's peaceful intentions. The 'harmonious relations' framework that this article introduces is a tool for capturing and analysing these embedded relationships and representations. It uses concepts of harmony as a heuristic for critically appraising music's potential contributions to peace in development contexts, synthesising ideas about relationships in peace and music from peace studies, musicology, philosophy and anthropology. The case of the Zohra Ensemble from Afghanistan illustrates its application.
\end{abstract}

\section{Keywords:}

Music; Harmony; Music-based peacebuilding; Intercultural music ensembles; Afghan music; Ethnomusicology; Zohra Ensemble; Relational peace 


\section{Introduction: Music as a peacebuilding vehicle}

Human development in the wake of armed conflict is a multi-dimensional challenge. It requires attention to psychosocial, cultural, and environmental needs in addition to political and economic concerns, and strategies that work from the bottom up as well as at the state level. Increasingly, the potential for artistic processes to support psychosocial recovery and cross-community connections has seen the arts included in community-level post-conflict development programs, including in support of peacebuilding (e.g. Cohen 2005; UNDP \& UNESCO 2013). This article considers the use of music activities to support peace and development goals and presents a theoretical contribution in the form of a framework for analysing the dimensions in which their contributions occur.

Music-based peacebuilding refers to musical activity with peacebuilding or conflict transformation goals. Most activities follow one or more of three broad approaches: music as representation; music as a joint activity; and music as an emotional tool (Bergh 2010). Music as representation connects music performances to a particular identity-group (or groups) as an index to encourage the audience towards a more nuanced and sympathetic understanding or recognition of the group(s) being represented. Music as a joint activity aims to forge relationships, dialogue and/or empathy through shared, participatory music-making, while music as an emotional tool uses music to modify people's moods and generate connections through shared, emotion-laden listening.

The first two approaches - music as representation and music as a joint activity - are the most prevalent in peacebuilding contexts, and they frequently co-exist. Such projects use musical activity to bring together people who (or sounds that) represent conflicting ethnoreligious or cultural groups. Music and music-making are positioned as sites of common interest and cooperation through which dialogue is facilitated and the seeds of empathy are sown. When the outcomes of this activity are presented to an audience, the meaning that is associated with the performance draws as much upon the representation of relationships between the particular identity-groups as it does upon the sounds that are being produced. Examples of this kind of intercultural 'co-existence' musical project include an Israeli Jewish-Arab duo representing Israel in the Eurovision Song Contest (Belkind 2010) or folk music festivals that present Sinhalese and Tamil folk musicians blending their traditional sounds, rhythms, and dances in post-civil war Sri Lanka (Howell 2019). ${ }^{i}$ While music-based peacebuilding can encompass activities that do not conform to this 'music-as-representation' 
model, intercultural ensembles of this description are the focus of my interest and argument in this article.

When music activities are instigated with the intention of building peace, organisers often build support and legitimacy for their project by evoking widely accepted tropes that associate music with prosocial outcomes and universal meaning. However, music is ambivalent (Urbain 2018). Critical studies of music and violence show music to be an effective instrument of torture, humiliation, and dehumanisation (Cusick 2006; Grant 2013). In addition, research at the nexus of music education, social justice, and human rights has demonstrated that systems of music learning can reproduce and reinforce structural injustices connected to cultural hegemony (Sandoval 2016). Unexamined assumptions about the universality of musical meaning overlook or ignore this potential for unintended harms (Cohen 2008), and musical collaboration between majority and minority group representatives does not necessarily include re-negotiation of existing power relations or challenges to the status quo social hierarchies (Beckles Willson 2013). Similarly, a musical performance that signifies geopolitical peace to its audience may not necessarily be a peaceful or even enjoyable experience for the players (Baker 2014). Ultimately, the declared peacebuilding intentions of a musical-social project are unreliable indicators of the actual project outcomes and experiences across the participant group(s).

Given this ambivalence, for music activities to be effectively included as strategies for strengthening peace post-conflict, their mechanisms for creating meaning and social change need to be contextualised with reference to the norms, values, and power dynamics of their setting and participant groups. Towards this, scholars from music sociology, arts education, ethnomusicology and political science have examined whether music can contribute to peacebuilding (Bergh 2010) and the mechanisms and power arrangements through which contributions occur (Odena 2010; Pruitt 2013). This article contributes to this conversation, proposing a framework for studying the multi-layered messages about peace and peacepromoting relationships that musical activity communicates. The framework synthesises three sets of ideas about relationships in peace and music: the relational concept of peace; music as a gestural language that communicates ideals about relationships; and harmony as a representation of relationships in both social and musical domains.

I begin with a brief outline of the concept of relational peace. I then summarise the ways musical action expresses and enacts relationships that its participants - or power-brokersconsider 'ideal'. Next I offer a synthesis of concepts of harmony that are the building blocks 
for the analytical framework that follows. In the last section I apply the framework to the Zohra Ensemble from Afghanistan, illustrating the relationships and ideas about peace it helps to bring to the fore.

\section{Relational peace and musical relationships}

In line with the field of ethnomusicology, I understand music (the sounds, and the act of making music with others) to be an essential part of human existence, a universally-shared trait that humans have used across millennia to explore, affirm, celebrate, make sense of and live well within their world (Blacking 1973). In this view, all people are musical, and while we can partake in music alone, it is - like language - fundamentally something that we share with others, a medium for social connection and interaction (Turino 2008).

Within this perspective, it is in the experience of relationship that the meaning of playing and listening to music lies (Small 1998), indicative of an alignment with the relational concept of peace (Söderström et al. 2020). Relational peace is studied through analysis of relationships. It considers behavioural interactions, subjective attitudes, and how the relationship is perceived by the involved parties. A peaceful relation should feature behavioural interactions of non-dominance, deliberation and cooperation. Söderström and colleagues use the relational peace concept to focus in particular on dyads; however, it also has utility when considering the multidirectional and interdependent relationships portrayed and enacted within musical action.

Critical peace scholarship also reminds us that conflicting parties in the same setting frequently define peace and its associated relationships and social ordering differently (Gusic 2020). These competing constructs of peace can also be modelled within musical action and the relationships it enacts, making it important to excavate the layers of relationship to reveal where non-dominance, deliberation and cooperation are enacted. Musicologist Christopher Small's (1998) neologism of musicking, outlined in the next section, offers a useful tool for this task.

\section{Conceptualising the relationships that musicking brings into existence}

In the introduction I outlined Bergh's (2010) typology of approaches to using music to build peace in development contexts and contained the scope of this article to the first two of these, music as representation and musicking as a joint activity. These two approaches situate the peacebuilding contributions of music in two distinct registers: as a representation of relationships between peoples (e.g. ethno-religious groups) as experienced by audiences; and 
through the creation of relationships between individuals through the shared experience of collaborative musical action. In the first approach, the musical ensemble symbolises and idealises a cooperative intercultural society, invoking the longstanding precept of ensembles as metaphors for society (Spitzer 1996). In the second, the music-making process facilitates relationships among players, creating new space for intercultural dialogue, cooperation, and affective bonds.

Both of these possibilities can be explained through Small's (1998) contention that the meaning of musical acts lies in the relationships that they bring into existence. Expanding on Bateson's (1979) work on biological communication, musicking (Small's proposed gerund of the verb 'to music') is understood as an act (in contrast to the more prevalent concept of music as a 'thing' that exists autonomously of its context and creation) that uses the paralanguage of gesture to communicate complex information about relationships and context. In particular, Small contends that musicking brings into existence relationships that model, or stand as metaphor for, ideal relationships as the participants in the performance imagine them to be: relationships between person and person, between individual and society, between humanity and the natural world, and even perhaps the supernatural world. (Small 1998:13)

Understood thus, musicking is an enactment ritual in which members of a social group explore and "affirm to [them] selves and others who [they] truly are or wish to be" (Boeskov 2017:88). Relationships between sounds, between players, between performers and audiences, between humans and the place in which the music is happening, between the musical event and the wider society, and between past, present, and future time are all encapsulated and have significance within the musical act in its context.

Note however that some participants will have greater power than others to determine what relationships are ideal. What is ideal for some is not necessarily ideal for all. Musicking therefore brings idealised relationships into existence that can mask ambiguities and contestation (Boeskov 2017).

Small's theorising helps to explain how music communicates through different registers simultaneously, necessitating attention to all the relationships that are being represented and enacted in the context of the musical action. Relational peace draws attention to the quality of these relationships, and their representations of non-domination, deliberation, and cooperation. The third building block of the 'harmonious relations' framework uses concepts 
of harmony as a heuristic for critically analysing relationships in music and peacebuilding contexts.

\section{Conceptualising harmony: Enduring models of idealised human relationships}

Concepts of social harmony can be found in Eastern, Western, and Indigenous philosophies. Broadly referring to diverse peoples living together agreeably, as well as the effect created through the simultaneous sounding of two or more musical tones, harmony's inclusion in both musical and social lexicons make it something of a 'false friend' for music-based peacebuilding. Used to simultaneously denote "a description of musical action [and] the desired project outcome" (Howell 2018:2) and to lend social authority to musical projects with purely aesthetic goals (Fink 2016), harmony can be an appealing albeit simplistic explanation for any prosocial and peace-promoting outcomes connected to music activity. At the same time, this lexical ambiguity invites us to think metaphorically about musical action, providing tools for appraising the relationships between sounds as well as between people.

Harmony can be understood as a variety of relational peace. In its different conceptualisations, it is in the interactions of dominance (or non-dominance), cooperation, and how the entities describe the relationship that harmonious and peaceful relations are created, defined, and sustained. Here I draw upon a set of conceptualisations of harmony developed in Howell (2018) — harmony-as-order, harmony-as-blend, and harmony-asconflict-avoidance (consonance) — and consider their representations of non-dominance, cooperation and deliberation.

"Harmony-as-order" is a model of harmony that is achieved when "the different layers of society [leaders, enforcers, workers] conform to the expectations of their roles and life station" (Howell 2018:5). To achieve harmony-as-order, harmonising is necessary, albeit with differing implications for agency and therefore the dominance and cooperation of relational peace. As a top-down action, one actor can harmonise others (i.e. bring all the layers of a society into order), where those being harmonised obey directions and relinquish their agency. A horizontal application of harmonising is also possible, when an actor nominates to harmonise with another. In music, this means adding a tone that complements the other tone(s). In social settings "actors impose [harmony] on themselves by adjusting their agency in line with others' behaviours and expectations" (Beyer \& Girke 2015:228). The emphasis on social hierarchies and sanctioned roles in harmony-as-order make it highly vulnerable to dominance and authoritarian coercion (Nader 1990). Agency for those lower 
down the hierarchy is therefore crucial if this concept of harmony is to produce relational peace. It is not a matter of replacing order with freedom - that would produce anarchy-but of realising the threshold at which order can be enjoyed while still protecting agency and freedom from arbitrary authority (Rockman 2010).

Through act(s) of harmonising, another model of harmony emerges: harmony-as-blend. Harmony-as-blend is "constituted through the combining and blending of all the diversity ... in society towards a functional whole" (Howell 2018: 5). However, this model contains ambiguous messages about diversity and how different voices are valued. Is there equal space for all voices, or are some sounds privileged? With its focus on the finished product, harmony-as-blend could be said to give greater value to homogeneity, encouraging the erasure of those elements that are less easily blended and reproducing the power of the most dominant actors. For harmony-as-blend to produce peaceful relations, a balance must be negotiated between diversity and homogeneity, and the social value bestowed upon one interest at the expense of the other.

A third enduring model, harmony-as-conflict-avoidance, frames diversity and difference as potential sources of conflict and something to be managed. When combined with the idealisation of order, this produces a version of harmony where "individuals subordinate their personal interests to those of the collective" (Howell 2018:6, citing Leung et al. 2002). This model can make agreement a moral obligation, privileging community unity and surface consensus over dealing with the conflict of dissent and legitimate claims for justice.

Here, the musical concepts of consonance and dissonance provide a more nuanced role for conflict in harmony. Consonance, or agreement of sounds, is defined through the absence of discordant sounds, and is implied in definitions of musical harmony in the mainstream Western discourse. But harmony in music also includes dissonance. For Adorno, dissonant intervals are "the actual vehicles of expressive character" (Adorno 2007 [1947]: 43) in music, their jarring and challenging qualities highly productive of the ignition of new ideas.

Furthermore, it is in dissonance that relationships between sounds are articulated most clearly (42). Extending this potential to the social realm, Korum (2020) proposes that dissonance can be understood as a critical encounter with the Other, and notes that, while sometimes provoking conflict, such encounters can stimulate curiosity, motivating actors to engage in the critical negotiations of difference and the 'moral imagining' of desired but not-yetexistent social change (Lederach 2005). To move conflict-avoiding harmony beyond the production of negative peace (absence of violence), there is a necessary engagement with 
alternative ideas and dissenting (dissonant) voices. A tension within harmony-as-conflictavoidance is therefore the extent to which it can sustain peace while still fostering the dissonance of creativity, new recognitions, and subaltern agency (Rockman 2010).

The above discussion has shown that harmony can be pursued by both top-down, authoritarian means as well as bottom-up, horizontal, and agentic means. Furthermore, it has demonstrated that people in all societies and at all social levels place high value on social order, blended unity, and forging consensus, recognising the resulting stability and security to be of value to all and not just those in power (Beyer \& Girke 2015:235). Harmony therefore has the potential to manifest as relational peace, but in order for the characteristics of nondominance, cooperation, and deliberation to ascend, it requires the productive co-existence of

- the stability and control of order with the possibility and opportunity of freedom;

- the unity and coherence of blend with the political voice and recognition within diversity

- the reassurance and safety of consonance with the disruption and creative ignition of dissonance.

While these pairs might appear as oppositional binaries, it is their potential to co-exist that is of interest here. Within each paired co-existence is the possibility of harmonious relations characterised by non-dominance, cooperation, and mutual deliberation, found at a critical threshold between each that provides unity and stability while not relinquishing voice and agency and their potential to foster desired social transformations. The threshold between each pair will be determined by the actors within each context, and is necessarily dynamic, a harmony realised through constant negotiation between local norms and present conditions.

\section{Analysing the quality of relationships and varieties of peace in music-based peacebuilding}

To apply this understanding of harmony to intercultural music-based peacebuilding activities, I present an analytical approach that uses questions as prompts, organised according to the relationships between sounds, people, and place that are brought into existence through musicking. They are not intended here as research questions; rather their function is to help to surface the enactments/representations of order, freedom, blend, diversity, consonance and dissonance within the musical action. While not exhaustive, the questions offer a method for 
critically and systematically analysing music-based peacebuilding action and its embedded relationships across multiple registers.

\section{The sounds:}

Challenges to, or reproduction of, the status quo ordering of society can be reflected through the ordering, weighting and blending of sounds, and how sonic discord is handled. Consider the provenance and socio-cultural status of the practices (instruments, performance techniques, systems of sound ordering) that are featured, and the extent to which one set of sounds may be positioned as the 'default'.

\begin{tabular}{|c|c|}
\hline Harmony varieties & Questions to ask \\
\hline $\begin{array}{l}\text { Geopolitical/ethno-political } \\
\text { ordering }\end{array}$ & $\begin{array}{l}\text { What (people, places, or situations) does the cultural heritage of } \\
\text { each instrument represent? } \\
\text { What does their combining/blending represent in terms of } \\
\text { current/historical geopolitical issues? }\end{array}$ \\
\hline Sonic ordering and freedom & $\begin{array}{l}\text { What system of sound ordering (e.g. composition/improvisation) } \\
\text { guides their exposition? (i.e. which cultural system is the default } \\
\text { template? Whose agency determines the choice of notes?) }\end{array}$ \\
\hline $\begin{array}{l}\text { Dissonance, consonance and } \\
\text { creativity (encountering the } \\
\text { Other); Blend and diversity }\end{array}$ & $\begin{array}{l}\text { To what extent are the sounds merely 'featuring' a set of } \\
\text { representative ethno-musical ideas, as opposed to being } \\
\text { transformed by them and therefore constituting new, transcultural } \\
\text { language? }\end{array}$ \\
\hline Power dynamics and interests & $\begin{array}{l}\text { Whose interests are served through the presentation of this } \\
\text { particular music in this time and place and what aspects of the } \\
\text { sounds are serving these interests? } \\
\text { How is the performance framed politically/economically? }\end{array}$ \\
\hline Other sonic symbols & $\begin{array}{l}\text { To what extent is conflict portrayed within the sounds (e.g. } \\
\text { resolved/unresolved, through patriotic/militaristic musical motifs)? } \\
\text { Conversely, to what extent are peace, harmony, or } \\
\text { (re)conciliation sonically portrayed? }\end{array}$ \\
\hline
\end{tabular}

Table 1: Interrogating the relationships embedded in sounds

\section{The practitioners (musicians, performers, composers):}

As the actors that bring the sounds into existence, the practitioners in musical action have dual roles. They are cultural-political agents who metaphorically 'stand for' an ethno-cultural or religious group, creating both visual and sonic spectacle for their audiences. They are also 
social agents, engaging in social interactions and relationship-building at the individual level through the musical collaboration. Order/freedom, blend/diversity, and consonance/dissonance are expressed through the practitioners' position within the ensemble hierarchy, how this subverts or reproduces the existing or historical ordering of the groups they represent, the space for creativity, negotiation and shared decision-making, and the capacity within the musical action for meaningful and nuanced encounters with the Other.

\begin{tabular}{|l|l|}
\hline Harmony varieties & Questions to ask \\
\hline Order and non-dominance & $\begin{array}{l}\text { How are identity, hierarchy or social order expressed in the physical } \\
\text { enactment of the sounds? } \\
\text { To what extent is equal status between the practitioners } \\
\text { visible/audible? }\end{array}$ \\
\hline Agency and order & $\begin{array}{l}\text { How agentic are the practitioners, in terms of the notes they } \\
\text { play/sing and their interpersonal interactions? } \\
\text { How are decisions made and actions determined? } \\
\text { What forms of harmonising are taking place? (Is one person } \\
\text { harmonising the sounds of others? Can one choose to harmonise } \\
\text { with another or is this an obligation?) }\end{array}$ \\
\hline $\begin{array}{l}\text { Blend and diversity; } \\
\text { dissonance and } \\
\text { consonance }\end{array}$ & $\begin{array}{l}\text { What opportunities exist for disrupting taken-for-granted conventions } \\
\text { of human social ordering (e.g. gender), blending of diversity, and } \\
\text { management of difference/conflict? }\end{array}$ \\
\hline $\begin{array}{l}\text { Power dynamics and } \\
\text { interests }\end{array}$ & $\begin{array}{l}\text { What characterises the relationships being enacted? For whom are } \\
\text { they 'ideal'? }\end{array}$ \\
\hline Relationship development & $\begin{array}{l}\text { What kinds of interpersonal relationships have room to flourish within } \\
\text { the timeframe of this project? Can they be maintained independently } \\
\text { beyond this project? }\end{array}$ \\
\hline
\end{tabular}

Table 2: Interrogating the relationships between participants

\section{The audience and external stakeholders:}

The audience(s) and external stakeholders of the musical action exist both within and beyond the performance context and hold power as investors (e.g. as ticket holders or sponsors). They are an influential force in determining the 'ideal relationships' that the musical action depicts, given the power asymmetry between gift-givers and receivers (Kowalski 2011). The goal is to reveal the wider web of motivations and relationships that brings them to this event. 


\begin{tabular}{|l|l|}
\hline Order, agency, dominance & $\begin{array}{l}\text { Who is the audience, and what is their (subjective/political) } \\
\text { relationship to the wider context of this musical action? } \\
\text { What are their existing or desired relationships with the } \\
\text { performers (or with the identity group(s) that the performance } \\
\text { represents)? } \\
\text { What (whose) conventions determine audience interactions with } \\
\text { the music and musicians? }\end{array}$ \\
\hline $\begin{array}{l}\text { Context for investment and } \\
\text { interest }\end{array}$ & $\begin{array}{l}\text { What is their motivation for being here? What is their interest } \\
\text { (political/economic/social/cultural) in the type of harmony/peace } \\
\text { being performed? (i.e. What does it mean for them?) }\end{array}$ \\
\hline
\end{tabular}

Table 3: Interrogating external stakeholder relationships

\section{The place and space:}

All space and its meanings are "heterogeneous and ever-becoming" (Gusic 2020:80), and alignment between these and peacebuilding goals will be revealed through critical engagement with the historical and current relationships between the performance site, the wider context, and the musical action in question across political, economic and cultural dimensions. Choice of site may reflect or upend norms of access and invitation (for the performers, audiences, external stakeholders, and sounds). The co-existence threshold between order/freedom, blend/diversity, and consonance/dissonance will depend upon individual and collective engagements with this particular place across time.

\begin{tabular}{|l|l|}
\hline Harmony varieties & Questions to ask \\
\hline $\begin{array}{l}\text { Order (social, political), } \\
\text { freedom, dissonance }\end{array}$ & $\begin{array}{l}\text { What are the cultural-historical overtones of this site? What } \\
\text { aspects of group belonging, dominance, and access does it } \\
\text { symbolise? What normally occurs here? }\end{array}$ \\
\hline Power dynamics and interest & $\begin{array}{l}\text { Whose interests are served through this musical action taking } \\
\text { place here, in this particular time? }\end{array}$ \\
\hline Order, consonance & $\begin{array}{l}\text { Is the action embedded locally or detached from its context, and } \\
\text { why? }\end{array}$ \\
\hline $\begin{array}{l}\text { Consonance, dissonance, } \\
\text { order, agency }\end{array}$ & $\begin{array}{l}\text { What strategies will be deployed in this site if/when the external } \\
\text { conflict that the performers represent enters the site? }\end{array}$ \\
\hline
\end{tabular}

Table 3: Interrogating spatial-temporal-social relationships

These questions help to uncover the varied meanings that different stakeholders may draw from the same musical action. As an analytical tool, the framework reveals the qualities of relationships between actors and groups and therefore, the varieties of peace being portrayed. It can also be used as a planning and implementation tool, assisting project organisers and 
practitioners to attend to the dynamics of order, freedom, blend, diversity, consonance (conflict avoidance) and dissonance (creativity and newness) represented in the different relationships in their project, with the goal of enacting a coherent set of peaceful relations.

\section{Applying the framework to an exemplar project}

I now apply the framework and its questions to a music school in Afghanistan and one of its flagship performing ensembles, Zohra. The case illustrates the multiple layers of relationships and implications for peace that this analytical approach reveals, with the concluding discussion offering some further interpretation and contextualisation.

\section{Zohra, the Afghan Women's Orchestra of the Afghanistan National Institute of Music}

The Afghanistan National Institute of Music (ANIM) is a vocational school of music in Kabul, educating Grades 4 to 14. Inaugurated in 2010, it is an independent directorate for music education within Afghanistan's Authority for Technical and Vocational Education and Training. ANIM's founder/director Dr Ahmad Sarmast believes that music and music education are cornerstones of a just and civil society (Canadian Broadcasting Corporation 2015). Under his vision, ANIM aims to revive Afghanistan's music practices, restore the musical rights of the Afghan people, and transform the lives of disadvantaged young Afghans through music. ANIM has been lauded for its inclusive enrolment policies: educating girls alongside boys, enrolling students from Afghanistan's diverse tribes and ethnic groups without discrimination, and reserving fifty per cent of its places for street-working children and orphans. These commitments to human rights and inter-ethnic diversity have helped ANIM build a support base among the international community in Afghanistan and beyond its borders. The World Bank and the US State Department are just two of its major funders. ANIM embodies many of the rapid social and economic changes that Afghanistan has seen in the last two decades with the international community's support. Many people, particularly in urban areas, embrace modernisation and the opportunities it brings. But change agendas imposed by centralised government or foreign entities have historically caused considerable social upheaval, particularly for rural dwellers (Barfield 2010). Thus there exists a national discourse that frames foreign-supported modernising efforts as a threat to Afghan culture and Islamic values (Billaud 2015). Women's rights are a major site of contestation, and music is another. Despite Afghanistan's rich musical history, music has long been the subject of religious controls, censorship, and social stigma and was banned by the Taliban (Baily 2001). In current times, many people still see it as a shameful activity, particularly for girls and 
women (Doubleday 2007). This perspective has made ANIM the target of extremist threats and violence, including a suicide bombing attack at a performance in which one person was killed and Sarmast was seriously injured.

The Afghan Women's Orchestra — known as Zohra — began as a student initiative and has become one of ANIM's most prominent ensembles. Zohra and other ANIM ensembles frequently perform internationally, their concerts framed as cultural diplomacy and 'messages of peace' that offer international audiences a more positive image of Afghanistan than that of war. Inside Afghanistan, ANIM gives concerts for government and international diplomatic communities, local social care and health providers, and vetted community audiences including children. It regularly releases music videos of original songs performed by ANIM's choir and orchestra. These songs disseminate human rights messages and are high-quality productions that portray gender equality in action. Alongside news media stories of ANIM's overseas and local performances, the videos increase the visibility of the school and its students within Afghanistan.

I have been researching the work of ANIM since 2013, gathering data via participant observation on an ANIM choir tour to Dubai in 2015, interviews with participants via Skype and in person, and analysis of documents and media footage, including of the international tours of the Afghanistan Youth Orchestra tour (USA, 2013) and Zohra (Switzerland and Germany, 2017 ${ }^{\mathrm{ii}}$, and Melbourne, Australia, 2019). In this analysis I limit my comments to Zohra's concerts in Davos and Melbourne ${ }^{\mathrm{iii}}$.

The sounds: Zohra is one of ANIM's hybrid ensembles, combining traditional Afghan instruments with Western orchestral instruments. It performs traditional Afghan music, newly commissioned work, and repertoire that reflects the cultural heritage of the performance site (e.g. Beethoven's Ode to Joy in Europe). The instrumentation reflects Afghanistan's diverse musical heritage: folk and classical instruments "from different parts of Afghanistan ... thereby symbolising the unity of the country" (ANIM 2014: 9); Hindustani instruments (e.g. sitar, sarod, adopted by the $19^{\text {th }}$ century Afghan royal court); European wind and brass instruments introduced to the Afghan army by British-Indian bandsmen (Sarmast 2004); and European string instruments, piano, and orchestral percussion. The instrumentation resembles the Arkestar-e Bozorg Radio Afghanistan (Big Orchestra of Radio Afghanistan), founded in 1970 and celebrated in its time as Afghanistan's 'national sound' because of its blending of musical elements from different ethnic groups (Sakata 2012; Sarmast 2004). However, with 
its inclusion of cello, viola, and oboe, Zohra's instrumentation presents greater timbral diversity than Arkestar-e Bozorg.

Zohra's concerts in Davos and Melbourne opened with musical numbers featuring the Afghan instruments alone, followed by the full orchestra. The Afghan instrumental group performed its music from memory. In the hybrid orchestra, all performers followed writtenout parts. Improvisation - an element in Afghan art music but not European classical or Afghan folk music - is not present. Western timbres outweigh Afghan timbres numerically and sonically: the bass, piano, percussion and cellos provide the lower registers, while melodic material is shared between Afghan and European instruments. Most of the Afghan folk song arrangements use Western harmonic language, replicating the orchestration styles used in the Arkestar-e Bozorg that "polished" folk songs according to European techniques (Sarmast 2004:325). In some pieces, the standardised tuning of the Western instruments subdues the microtones, pitch-bends and non-Western intervals that characterise Afghan musical language. In these ways, while the Afghan sounds retain distinction in the blend, Western musical conventions enjoy default status.

The practitioners: Zohra's performance dresses feature the intricate geometric embroidery for which Afghanistan is known. Players of Western instruments wear a contemporary adaptation of traditional dresses in black, with red headscarves. Players of Afghan instruments wear brightly coloured Pashtun robes, imprinting a proud Afghan identity on the opening music. This uniformity of dress, across what Sarmast describes as ANIM's "beautiful mosaic of Afghan ethnicities" (Rasmussen 2015:para.20), emphasises a shared identity, reinforcing the metaphor of national unity across diversity. The students embrace their collective identity: "Before being Hazara we are Afghan, before being Afghan we are Muslim, and before being Muslim we are human” (Zarifa in WEF 2017:para.4).

In these concerts, Zohra follows the Western orchestral performance paradigm with ordered seating (players of Afghan instruments front and centre, seated as per tradition on the carpet, players of Western instruments on chairs or standing), top-down direction, and disciplined cooperation. A conductor 'harmonises' and directs the players (apart from the traditional Afghan ensemble, where the performers communicate without visible hierarchy). In Davos two female students conducted the orchestra, a significant celebration of female leadership given the lower status of women in Afghan public life and scarcity of female conductors globally. In both Davos and Melbourne, student representatives joined ANIM's Director and a local moderator in public discussions about music in Afghanistan. These conversations 
noted the dangers and risks for female musicians in Afghanistan but also the young women's pride in being role models for other young women, in contributing to Afghanistan's cultural revival, and in being able to share Afghan music internationally. These articulations of agency, coupled with their visible confidence and pleasure during their performances, also signal the students' inclusion in Afghanistan's educated, cosmopolitan class (Billaud 2015). We can imagine the considerable cultural distance between their school experiences and the rural origins and/or conservative family backgrounds of some students.

An additional set of practitioner relationships are those between Zohra and musicians from the host community. Designated as cultural exchange, the young host musicians augment Zohra's sounds, sharing music stands and parts. Their youthfulness offers a metaphor for future cooperative relationships between their countries; however, the quality of relationship between the two groups cannot be presumed. In Davos, ANIM's Director stated that the common language of music enabled these supportive relationships to flourish ${ }^{\mathrm{iv}}$. Certainly, factors such as the printed notation and shared enculturation into Western music conventions are pragmatic essentials for the cooperation's success. Lasting relationships will depend upon opportunities for socialising, common language and resources for continued connection, not simply the musical engagement (Howell 2019).

Audiences and other stakeholders: Zohra's concerts in Davos were part of the cultural program of the World Economic Forum, an annual gathering of global political and business elites. Its attendees represent powerbrokers in international development, including ANIM's major sponsors. This invited audience has invested heavily in the liberal peacebuilding process in Afghanistan, and Zohra offers a symbol of shared progress, given the ban on music and the invisibility of women during Taliban rule. The WEF talk session involving the two Zohra conductors and Dr Sarmast, Artists on the frontlines: Fighting the Taliban with Music, unambiguously aligns Zohra and ANIM with the goals of the US-led intervention. This is an emotion-stirring event for the WEF: we see a woman wiping away tears during 'Ode to Joy' (ANIM 2017: part 3). Television cameras fill the aisles, indicating audiences beyond those present (such as the online audience of which I am part).

Afghanistan's diaspora community dominated Zohra's audience in Melbourne. Tickets sold out prior to the concert, and attendees included independent purchasers and guests of the host university and the main corporate sponsor, an Afghan-owned local business. With the concert coinciding with the 50th anniversary of Afghanistan-Australia diplomatic relations, the Afghan Ambassador to Australia gave an opening speech, describing Zohra as "sharing a 
message of hope for peace". He prompted spontaneous applause when he declared, "every clap in this concert will be a slap in the ugly face of extremists including the Taliban"》. This applause indicated audience opposition to the extremists' cultural and political goals, implying support for their eradication. Midway through the concert, the Director of the host university's Gender, Peace, and Security research centre led an on-stage conversation with a Zohra member and Dr Sarmast about music in Afghanistan, declaring that "playing music is a sign that peace is possible". That discussion situated Zohra and ANIM in Afghanistan's peace process and therefore of interest to the university's gender, peace, and security researchers. Audience attendance at the concert suggests diaspora interest in Afghanistan's music traditions; additionally, Zohra may represent socio-political changes that they want to see in Afghanistan. For older audience members, Zohra may prompt nostalgic recollection of the Arkestar-e Bozorg and other Radio Afghanistan ensembles. The fact that ANIM's founder and director is the son of that orchestra's celebrated conductor and composer helps to consolidate this sense of continuity of tradition.

Space and place: Zohra gave the Closing Concert of the World Economic Forum. Footage indicates a multi-use room with flexible seating, rather than a purpose-built concert space. Zohra performed in front of a projected backdrop featuring countryside images. As a global agenda-setting site not open to the public, the event was relatively detached from the local or regional context. The country of Switzerland can be read as symbolising European wealth and influence, and therefore an important resource of support for both ANIM and the Government of Afghanistan.

In Melbourne, Zohra performed in a concert hall (part of the host university's music department) famed for its fine acoustics and located in an outer suburb. Cocktail functions for invited guests preceded and followed the concert. University leaders opened and closed the event with heart-felt speeches that framed the concert as a hopeful augury of peace. An additional significance of the location is that the host university is Dr Sarmast's alma mater (he completed his $\mathrm{PhD}$ there in 2004) and Melbourne is his adopted home. This was the first time an ANIM ensemble had performed in his city of exile.

\section{Discussion}

Building peace in Afghanistan has been long and complex, with a US-led military intervention and a largescale international project of statebuilding, reconstruction, and sociocultural transformation. Billions of dollars have been expended and hundreds of 
thousands of lives lost, yet Afghanistan is more, not less insecure (Mason 2011). As well as the territorial battle between ethnic or tribal factions, Afghanistan's conflicts are cultural and ideological, in which competing narratives of national identity vie for ascendance. This cultural battle has intensified since the US-led invasion, continuing a well-established pattern of civil strife and religious radicalisation in response to top-down modernising reforms (Billaud 2015). This implicates foreign-led development and statebuilding in any efforts to build peace in Afghanistan and makes peace both an international and intrastate concern.

In its performances and sounds, Zohra depicts varieties of peace focused on international and intrastate relationships. The former is represented through Zohra's sonic and visual portrayal of Afghanistan's regional links as well as East-West dialogue and blending. Afghan musical traits are often foregrounded, suggestive of voice and agency; however, the heft of Western sonic scaffolding intimates a broader socio-political architecture in which Western dominance is retained. Conductors and orchestrations together ensure an ordered, predictable and consonant harmony. Meanwhile, Zohra's performances claim a more equal share of Afghanistan's cultural space, presenting women as contributors and leaders. This corresponds with the human rights discourse embedded within the liberal peace paradigm that the international community has pursued in Afghanistan, with its combination of top-down regulations and freedoms (Richmond 2008).

Peace through intrastate relationships is depicted through Zohra's blend of Afghan instruments and presentation of folk songs from around the country, combined with the ensemble's inter-ethnic membership. This peace is arguably more legible for Afghan audiences than non-Afghans, as the provenance of the music is not announced, leaving those unfamiliar with the songs unaware of the subtext of their inclusion. Similarly, non-Afghan audiences might be less able to distinguish the different ethnicities that the performers represent. But for its diaspora audiences, Zohra invokes pride in shared Afghan identity. Many Afghans associate their rich music traditions with their Afghan identity (Baily 2015) and Zohra portrays a more positive view of Afghanistan than that associated with the Taliban, four decades of war, and failed Western intervention.

For Zohra's Davos audience, the variety of peace Zohra performs confirms the state as the dominant actor in realising peace, indicating top-down, order-focused harmony. But consideration of the performer-audience power relationship reveals additional aspects to this depiction of peace. By embodying the positive changes that international intervention has sponsored, Zohra's performances can be appropriated as a form of public diplomacy, helping 
donor governments revive support for their interventions in Afghanistan among their domestic audiences (Wright 2017). Similarly, support for cultural initiatives like Zohra can help to mask the destructive aspects of the military occupation that co-exist alongside its achievements (Goodhand \& Sedra 2013). With music and young women's involvement in it still contested in Afghanistan, and many Afghans' wariness of foreign interference and centralised rule, this use of Zohra as a diplomacy tool has some concerning implications. While ANIM is an Afghan endeavour, international sponsorship of (and demand for) student performances increases their local visibility, making students more of a target for violent acts. Public political declarations (e.g. anti-Taliban) potentially position Zohra's musicians - many of whom are children-less as peace actors than symbols of international and state objectives on one side of an unresolved conflict.

However, an actor-oriented interpretation (Long 1990) brings the Zohra musicians' agency to the fore, rather than their instrumentalization. They care about their country's international and intrastate future and wish to play a role in shaping it. Studying at ANIM enables them to get educated and pursue something they love, gaining recognition (notoriety as well as admiration), and the social mobility that comes from sought-after opportunities like international travel and scholarships. It also enables them to act in service to their country, as 'pioneers' in a mission of restoring cultural rights and paving the way for future generations to learn and play music if they wish, or to realise other dreams. Service, recognition, and heroic self-sacrifice are important cultural and moral values for young Afghan women (Eggerman \& Panter-Brick 2010; Billaud 2015). This sense of purpose helps them reconcile the familial and social tensions their choices exacerbate, and the dangers they face as a consequence. Those that speak publicly (at concerts and to the media) state that the hardships they face are worth it.

This narrative of Zohra depicts a peace founded on rights and equality. Within it, ANIM and Zohra function as 'spaces of agency' in which rights can be claimed and peace can flourish (Kappler 2014: 38). The road to that peace is necessarily dissonant and unpeaceful because it brings currently opposing ideas into encounter, particularly around notions of morality, honour, and obligations for young women. Yet, as the grassroots peace movement in Afghanistan argues, a peace that removes women's rights will not bring the durable peace that most Afghans desire (Zia \& Thompson 2020). Interpreted thus, Zohra offers a story of Afghan agency rather than simply one of Western influence, depicting a pan-Afghan peace with justice and inclusion its foundational values. 


\section{Conclusion}

In this article I have brought together theory from ethnomusicology, musicology and peace studies to develop a conceptual and analytical framework that facilitates critical analysis of musical action with peacebuilding goals, with relationships the central object of interest. Christopher Small's theorising about how musical meaning is constructed draws attention to the relationships between sounds, people, and place that are central to musical meaning. Harmony offers a salient lens through which to apprehend the quality of these relationships, and to develop a nuanced understanding of their enactments of order and freedom, blend and diversity, consonance and dissonance. Harmony is understood as a type of relational peace, with characteristics of non-dominance, cooperation, and deliberation discernible in both musical and social constructions of harmony.

Developing a more nuanced understanding of how music communicates and makes meaning is key to its effective use as a tool in building peace and reconciliation. Musical action is always imbued with and mediated by power relations (Araujo 2010), embedded within adherence to traditions and enactments of wider norms of societal organising. These need to be scrutinised across the different registers through which music communicates, if we are to draw critical conclusions around what is being contributed, and identify those aspects working for different versions of peace. The framework addresses the complexity of music and its relationships as contributors to peace, helping to reveal internal contradictions between peace-promoting intentions, in support of more effective, coherent, peace-promoting musical action.

\section{Acknowledgments}

Thanks and appreciation to Professor Brydie-Leigh Bartleet, Director of the Queensland Conservatorium Research Centre, Griffith University, for supporting my research with a Postdoctoral Research Fellowship in 2019-2020. This article was drafted in the stimulating research environment of the QCRC. Thanks also to the two anonymous reviewers and the editorial team for their critical feedback and suggestions, which improved the article enormously.

\section{ORCID iD}

Gillian Howell https://orcid.org/0000-0002-5621-8143 


\section{References}

Adorno, T. W. 2007 [1947], Philosophy of modern music, London \& New York: Continuum. Araujo, S. 2010, 'Sound praxis: Music, politics and violence in Brazil' in O'Connell, J.M. \& Castelo-Branco, S., eds, Music and Conflict, Urbana, IL: University of Ilinois Press 217-231

ANIM. 2014. 'Afghan Youth Orchestra at Royal Opera House, Muscat.' in Concert Program, Oman: Royal Opera House Muscat.

ANIM. 2017. 'The story of Zohra', ANIM, Accessed 22 May, https://www.zohra-music.org/. Baily, J. 2001. "Can you stop the birds singing?": The censorship of music in Afghanistan, Copenhagen: Freemuse.

Baily, J. 2015, War, exile, and the music of Afghanistan: The ethnographer's tale, Farnham, Surrey, UK: Ashgate.

Baker, G. 2014, El Sistema: Orchestrating Venezuela's youth, New York: Oxford University Press.

Barfield, T. 2010. Afghanistan: A cultural and political history, Princeton, NJ: Princeton University Press:

Bateson, G. 1979, Mind and nature: A necessary unity, New York: Dutton.

Beckles Willson, R. 2013. Orientalism and musical mission: Palestine and the West. Cambridge UK: Cambridge University Press.

Belkind, N. 2010, 'A message for peace or a tool for oppression? Israeli Jewish-Arab duo Achinoam Nini and Mira Awad's representation of Israel at Eurovision 2009' in Current Musicology 45: 89: 7-35.

Bergh, A. 2010, 'I'd like to teach the world to sing: Music and conflict transformation', $\mathrm{PhD}$ dissertation, University of Exeter.

Beyer, J. \& Girke, F. 2015, 'Practicing harmony ideology: Ethnographic reflections on community and coercion' in Common Knowledge 21: 2: 196-235.

Billaud, J. 2015, Kabul Carnival: Gender Politics in Postwar Afghanistan, Philadelphia: University of Pennsylvania Press.

Blacking, J. 1973, How musical is man? Seattle, WA: University of Washington Press.

Boeskov, K. 2017, 'The community music practice as cultural performance: Foundations for a community music theory of social transformation' in International Journal of Community Music 10: 1: 85-99. 
Canadian Broadcasting Corporation. 2015 (17 July). 'Risking it all' in This Friday on q, accessed 01 June 2020, https://www.cbc.ca/radio/q/schedule-for-friday-july-17-20151.3156482

Cohen, C. 2008, 'Music: A universal language?' in Urbain, O., ed, Music and conflict transformation: Harmonies and dissonances in geopolitics, London: IB Tauris: 26-39.

Cohen, C. 2005, 'Creative approaches to reconciliation.' in Fitzduff, M. \& Stout, C.E. (eds.), The psychology of resolving global conflicts: From war to peace, Westport, CT: Greenwood Publishing Group: 69-102.

Cusick, S. 2006, 'Music as torture/Music as weapon' in TRANS Transcultural music review, 10, accessed 27 March 2020: http://www.sibetrans.com/trans/articulo/152/music-astorture-music-as-weapon

Doubleday, V. 2007, '9/11 and the politics of music-making in Afghanistan' in Ritter, J. \& Daughtry, J. M., eds, Music in the post-9/11 world, New York: Routledge: 277-314

Eggerman, M. \& Panter-Brick, C. 2010. 'Suffering, hope, and entrapment: Resilience and cultural values in Afghanistan' in Social Science \& Medicine 71: 71-83.

Fink, Robert. 2016. 'Resurrection Symphony: El Sistema as Ideology in Venezuela and Los Angeles' in Action, Criticism, and Theory for Music Education 15: 33-57.

Goodhand, J. \& Sedra, M. 2013, 'Rethinking liberal peacebuilding, statebuilding and transition in Afghanistan: an introduction', in Central Asian Survey, 32: 239-54.

Grant, M. J. 2013, 'The illogical logic of music torture', in Torture, 23:2:4-13.

Gusic, I. 2020, Contesting peace in the postwar city: Belfast, Mitrovica, and Mostar, Cham, Switzerland: Palgrave Macmillan.

Howell, G. 2018, 'Harmony' in Music and Arts in Action [Special Issue: Keywords for Music in Peacebuilding] 6: 2: 45-58.

Howell, G. 2019, 'Music development and post-conflict reconciliation in Sri Lanka' in Böhnisch, S. \& Eidsaa, R., eds, Kunst og konflikt, Oslo: Universitetsforlaget: 227-248.

Kappler, S. 2014. Local agency and peacebuilding: EU and international engagement in Bosnia-Herzegovina, Cyprus and South Africa, Basingstoke, Hampshire: Palgrave Macmillan.

Korum, S. (2020), 'The sound of reconciliation? Musical and sociocultural harmony in the Sri Lanka Norway Music Cooperation (2009-2018)' in Asian-European Music Research E-Journal, 5: 51-65.

Kowalski, R. 2011. 'The Gift: Marcel Mauss and international aid', in Journal of Comparative Social Welfare, October: 189-203. 
Lederach, J. P. 2005, The moral imagination: The art and soul of building peace. New York: Oxford University Press.

Long, N.. 1990, 'From paradigm lost to paradigm regained? The case for an actor-oriented sociology of development', in European Review of Latin American and Caribbean Studies 49: 3-24.

Mason, W. 2011, 'Introduction' in Mason, W., ed, The rule of law in Afghanistan: Missing in inaction, Cambridge: Cambridge University Press, 1-12.

Nader, L. 1990, Harmony ideology: Justice and control in a Zapotec mountain village, Stanford, CA: Stanford University Press.

Odena, O. 2010, 'Practitioners' views on cross-community music education projects in Northern Ireland: Alienation, socio-economic factors and educational potential, in British Educational Research Journal 36: 1: 83-105.

Pruitt, L. 2013, Youth peacebuilding: Music, gender and change, Albany, NY: SUNY Press.

Rasmussen, S. E. 2015, 'He was the saviour of Afghan music. Then a Taliban bomb took his hearing' in The Guardian, May 25. Accessed 27 March 2020: https://www.theguardian.com/world/2015/may/25/he-was-the-saviour-of-afghanmusic-then-a-taliban-bomb-took-his-hearing.

Richmond, O. 2008, 'Reclaiming peace in International Relations' in Millennium: Journal of International Studies 36: 3: 439-470.

Rockman, B. 2010, "Open politics and disharmony' in Tao, J. et al, eds, Governance for harmony in Asia and beyond, Abingdon, Oxon.: Routledge, 189-209.

Sakata, H. L. 2012. 'Music in Afghanistan', Afghanistan: Multidisciplinary Perspectives, 17 : $1-5$.

Sandoval, E. 2016, 'Potential contributions of music education to peacebuilding: Curricular concerns' in Journal of Peace Education 13: 3: 238-251.

Sarmast, A. 2004, 'A survey of the history of music in Afghanistan, from ancient times to 2000 A. D. ', PhD dissertation, Monash University.

Small, C. 1998, Musicking: The meanings of performing and listening, Middletown, CT: Wesleyan University Press.

Söderström, J., Åkebo, M., \& Jarstad, A. 2020, online first, 'Friends, fellows and foes: A new framework for studying relational peace' in International Studies Review: 1-25. https://doi.org/10.1093/isr/viaa033.

Solomon, T. 2016, 'The play of colours: Staging multiculturalism in Norway' in Danish Musicology Online: Special edition: 17th Nordic Musicological Congress:187-201. 
Spitzer, J. 1996, 'Metaphors of the orchestra: The orchestra as a metaphor' in The Musical Quarterly 80: 2: 234-264.

Turino, T. 2008, Music as social life: The politics of participation, Chicago: University of Chicago Press.

UNDP \& UNESCO. 2013, 'Creative Economy Report 2013: Widening local development pathways', accessed 27 March 2020,

http://www.unesco.org/new/en/culture/themes/creativity/creative-economy-report2013-special-edition/

Urbain, O. 2018, 'Business and Music in Peacebuilding Activities: Parallels and Paradoxes' in College Music Symposium 58: 3: 1-16.

WEF. 2017. 'Artists on the frontlines', World Economic Forum, accessed 10 May. https://www.weforum.org/agenda/2017/01/artists-on-the-frontlines-fighting-thetaliban-with-music/.

Wright, K. (2017). 'Telling NATO’s story of Afghanistan: Gender and the alliance's digital diplomacy' in Media, War \& Conflict 12:1: 87-101.

Zia, E. \& Thompson, T. 2020. 'Afghan grassroots activists could help build a lasting peace' in United States Insitute of Peace blog. Washington DC: USIP.

\section{Author Biography}

Dr Gillian Howell is Dean's Research Fellow in Music at the University of Melbourne where she investigates the contributions of participatory music and arts to post-conflict peace and reconciliation, community development, and cultural development. She has worked in post-war music and development projects in Bosnia-Herzegovina, Kosovo and North Macedonia, Georgia, Sri Lanka, and Timor-Leste.

\footnotetext{
${ }^{\mathrm{i}}$ Further descriptions and critical discussions of these kinds of ensembles can be found in Beckles Willson (2013), Solomon (2016), and Urbain (2018).

ii This concert can be viewed at https://youtu.be/hyBoWUxWIEQ (accessed 19 March 2020)

iii ANIM's ensembles have given over 100 international performances since 2011, including in non-donor countries such as Uzbekistan, Pakistan and China. The two selected for analysis should not be considered representative of all of ANIM's audience relationships.

iv Time cue 51:25-51:36, https://youtu.be/hyBoWUxWIEQ (accessed 19 March 2020)

v Speech by Wahidullah Waissi, the Afghan Ambassador to Australia, New Zealand and Fiji, at Robert Blackwood Hall, Monash University, 12 October 2019. Quotes noted by the author while in attendance at the concert.
} 